\title{
3
}

\section{Off-course betting, bookmaking and the British}

$\mid$ n 1923 an assistant mistress of a London County Council boys' school reported that betting was fairly general in her class. While she and the head took this seriously, the boys treated it as nothing wrong, and her remonstrations as a joke. They were actually 'encouraged by their parents'. She felt helpless. She could not go to the police because 'in a poor neighbourhood it is a very dangerous thing to excite the animosity of the parents. ${ }^{1}$ The popularity of betting in that particular culture was clear. His Majesty's Inspectors of Schools felt in 1924 that such reports were exaggerated. ${ }^{2}$ HMI were in no position to know. Pupils were unlikely to boast to an unknown, middle-class visiting school inspector of their involvement in illegal gambling.

Betting was probably exceeded only by cinema-going as the leading leisure spending activity during the interwar years. ${ }^{3}$ The 1853 Betting Houses Act and 1906 Street Betting Act had both assumed that the perceived 'problem' of working-class cash betting could be substantially reduced by prohibition and police action. They were wrong. Enforcement was erratic, courts were unwilling to imprison offenders, and bookmakers evaded the law. By contrast both oncourse cash betting and credit betting remained legal. So credit bookmakers in most towns catered for middle- and upper-class off-course horserace betting.

Despite betting's popularity we still know less than we should about its social and cultural meanings. The two state-initiated reports on betting, those of the Select Committee on Betting Duty of 1923 and the Royal Commission on Lotteries and Betting of 1933, were concerned almost entirely with the supposedly adverse consequences of working-class betting, mediating the views of punters through the eyes and ears of anti-gamblers, police, bookmakers, the Jockey Club, or similar interest groups. A pathological view of betting, and the ethical, moral, social and economic arguments surrounding its consequences, dominated. The real meanings of betting for ordinary people were neglected. 
Recent academic research has also largely focused on working-class, 'popular' betting, reflecting contemporary state and press concerns, and interest in the economic difficulties of the interwar years. ${ }^{4}$ This has been deleterious to more nuanced analysis. The neglect of upper- and middle-class betting has unbalanced research findings. Credit betting was different from working-class cash betting. British betting cultures were highly complex in other ways too. Firstly there were clear national and regional variations in betting's nature and volume. Second, as Stevenson has pointed out, attitudes within different social strata, personality and temperament also played a part. ${ }^{5}$ We should further add age, gender, the nature of work or non-work, religion and ethnicity. The roles of police, publicans, punters and bookmakers were also different. The following sections begin to draw out British betting culture in more detail.

\section{Betting's interwar growth and regional variation}

Between the wars the cultural significance of betting was almost certainly at its twentieth-century peak. In Liverpool in the 1930s, the Pilgrim Trust found that the 'all pervading atmosphere of football pools, greyhounds and horses ... has become such an important environmental factor that ... it is an effort to develop interests unconnected with them'. ${ }^{6}$ The period 1919 to 1939 was important in terms of gambling growth. ${ }^{7}$ Alongside the rise in real wages the estimated amount spent on all forms of legal gambling rose from $£ 63$ million in 1920 to $£ 221$ million in 1938, ahead of other expenditure. Although these figures included football pools, gaming and greyhound racing as well as horseracing, the latter was the major betting medium. Figures on overall gambling expenditure as a proportion of total consumer expenditure rose consistently from 1.3 per cent in 1920 to 2.5 per cent in 1925, and rose again from 3.7 per cent in 1930 to 4.1 per cent in 1935. By 1938 gambling expenditure had reached an estimated 5 per cent of a much higher total consumer expenditure. ${ }^{8}$

Much of this was gambling on the horses, although greyhound racing expanded rapidly from the late 1920 s, and pools expenditure rose from $£ 10$ million in 1934 to over $£ 40$ million by 1938 . The actual amount spent by punters on racing each year aroused keen contemporary debate, marred by problems of evidence and definition. Those who wanted to demonstrate a high level of betting often used gross betting turnover, but bookies often hedged bets with other bookmakers to reduce potential liability. Betting money was always circulating from losers to winners. Someone betting at the races might start with $£ 1$, win $£ 2$ on two winning bets, and lose $£ 2$ on four others, and end up with the 
original pound, despite the $£ 4$ turnover. After considering widely differing views the 1923 Committee suggested an annual turnover of $£ 200$ million, and the estimate of the Racecourse Betting Control Board for 1929-30 was £230 million. The actual amount actually finally transferred by the end of each year to and from punters and bookmakers must have been much less. Bookies could always lose, and small bookies, who lacked economies of scale, went broke each year.

Such figures exclude the illegal and unrecorded street betting and sweepstakes, which probably substantially increased consumer expenditure figures, and the betting industry was certainly amongst the largest industries of the period. Even Seebohm Rowntree, no friend of betting, admitted that in York at least half the men bet, many of them each day during the flat-racing season. ${ }^{9}$ A cautious judgement by a leading economic historian of gambling is that off-course betting was 'probably increasing' at this time. ${ }^{10}$ Almost all of the witnesses to the 1923 Parliamentary Committee accepted that after a First World War lull betting almost immediately rose above pre-war figures. In most areas, prosecutions also rose, although at different rates: in Liverpool, for example, from 113 prosecutions in 1912-13 to 570 in 1921-22, in the Metropolitan Police District from 205 cases in 1912 to 269 prosecutions in 1922. The controller of the Central Telegraph Office believed that 7 per cent of general public telegraphic traffic was connected with racing. This was 'considerably in excess of before the war'. The number of convictions for street betting in the Metropolitan Police area rose from 2,520 in 1920 to 3,274 in 1922 . In $1919-20$ a total of 1,074 (mainly credit) bookmakers and turf commission agents were assessed for Income Tax Schedule $\mathrm{D}$ on the basis of $£ 425,265$ in assessed profits. By 1922-23 numbers had risen to 1,918 , paying $£ 1,040,232$ in assessed profits. As a result of considering such evidence the draft report concluded that betting had 'an appalling hold' on 'the large majority of the community. ${ }^{11}$

What were the reasons for this? Some contemporaries argued that gambling had increased because of the higher wages enjoyed by war workers. It is possible, indeed likely, that men in military camps, barracks or hospitals during the war filled their time in betting, and brought the habit home on demobilisation. Some felt that with the father away, children had been brought up with less discipline, and their 'natural instinct for self-gratification' had not been checked. ${ }^{12}$ It was suggested that an influx of demobilised soldiers and officers increased bookmaking numbers. ${ }^{13}$ Others, like Liverpool's chief constable, believed that after the war, 'the world has not settled down to the old humdrum experience', and the war had created 'a craving for excitement' which had led to a widespread 
change of attitude about betting. ${ }^{14}$ This had supposedly been exacerbated by the increased publicity given by the press to betting news.

Others linked this more generally to changes in urban social and working conditions. Drab living conditions and the increased mechanisation and specialisation of industrial work meant few opportunities to exercise skill, and betting enlivened a monotonous and unfulfilling working life. ${ }^{15}$ Some observers suggested that those who were struggling financially turned to betting for the chance of an occasional coup. Paradoxically, it was also suggested that betting was increasing because those with more money and more free time had increased opportunities to bet. Some portrayed it as a sickness, an 'infectious' vice, with tempted 'victims' trying to recoup losses or repeat the initial success. They also blamed a post-war increase in leisure time, the absence of more 'rational' amusements, and a lack of moral tone and guidance.

The size of any increase is difficult to determine. Formerly understaffed police forces could simply have put more of their resources into controlling betting on their return to peacetime duties, raising prosecution figures. One surrogate indication of the longer-term expansion of betting over the interwar years is a comparison of the census figures for bookmakers for 1921 and 1931, although these will have omitted most illegal cash bookmakers, and part-time workers like agents who collected bets on their behalf ('bookies' runners', 'takers' or 'lifters') or lookouts ('police-watchers'). In 1921 the census recorded 2,824 male bookmakers and 73 females. Of these some 326 men were employers, 1,040 were employees and 1,458 worked on their own account. By 1931 there were 9,330 male and 425 female bookmakers. This was a very impressive three-fold increase.

It is also clear that there was significant variation between regions, and different regional trajectories of change. Both the 1923 Committee and the 1932 Commission believed that betting was more prevalent in industrial towns and semi-rural industrial districts like Staffordshire or Durham. The number of bookmakers in different regions in 1921 and 1931 in census figures (Table 3.1) partially confirms this view. Regional variation was fairly consistent between the two censuses except in the case of the Birmingham district, which experienced rapid growth.

This was unsurprising since Birmingham was relatively prosperous between the wars. South Wales, which had the highest percentage of unemployment, showed the least growth. ${ }^{16}$ The North-east, with the highest unemployment rate of any English region, shows the second lowest percentage growth. So rates of growth were probably linked to regional prosperity. More detailed evidence 
Table 3.I Bookmakers in industrial areas of England and Wales, $|92|-3 \mid$

\begin{tabular}{lcc}
\hline & I 92 I census & I 93 I census \\
\hline Greater London & 452 & 1053 \\
Lancashire and parts of Cheshire and Derbyshire & 211 & 414 \\
Yorkshire West Riding and City of York & 135 & 277 \\
North-east & 79 & 148 \\
Birmingham and district & 48 & 187 \\
South Wales & 69 & 77 \\
\hline
\end{tabular}

Source: Census

from the registrar general presented to the 1923 Select Committee supports such variation, although it conflated bookmakers, clerks and 'agents'. In London alone in 1921 there were 739 male and 12 female bookmakers, clerks and agents. Middlesex had 135 males and 7 females, Surrey 120 male and 8 females; Essex 83 males and 1 female, and Kent 36 males and 1 female. By contrast the Yorkshire West Riding had 271 males and 4 females, the East Riding 50 males, the North Riding 34 males, and Lancashire 375 males and 7 females. ${ }^{17}$

In figures of bookmaker prosecutions Liverpool and Manchester were always at the top of betting prosecutions in the north of England, well ahead of Leeds, Newcastle and other large northern towns in proportion to their population, and other evidence appears to bear out the popularity of betting there. ${ }^{18}$ There were 1,034 convictions in Manchester in 1932 for a population of three-quarters of a million; Salford had 414 convictions in 1934 with a population of c.220,000, and Liverpool had 322 convictions in 1932 for a population of c.750,000. ${ }^{19}$ However, Salford had a vociferous anti-gambling lobby, and had regular purges supported by local magistrates and the Watch Committee. A year later in similar-sized Cardiff there were only 77 arrests, and in Leeds, which was twice the size, there were only $28 .^{20}$

We know less about rural interest in racing. Northern England mining villages were generally accepted as hotbeds of betting. One anti-betting campaigner believed that in the north of England there was 'less gambling in purely rural agricultural districts', but larger facilities in the mining districts of course [my italics]'. ${ }^{21}$ But experience varied. While the Scottish street bookmaker James Croll claimed that he had 'not seen any village that did not have a bookmaker', his compatriot James McLean felt that in the Highlands there were 'any 
amount of towns and villages where there is no bookmaker', and large parts where there was 'no betting at all'. ${ }^{22}$ Even in 1932/3 it was felt that the purely agricultural districts were 'without facilities for ready money betting'. ${ }^{23}$ Rural punters may have lacked bookmakers but village publicans took bets, and the telephone or post could also be used. ${ }^{24}$ In rural areas like North Yorkshire or the North Downs, where horses were bred or trained, there was significant interest in their later successes. ${ }^{25}$

\section{Betting in working-class communities}

Some British working-class betting was certainly careful, considered and calculated. Judgements were based on a study of the sporting press, form and other factors, although not all punters should be romantically assumed to be potential Albert Einsteins. ${ }^{26}$ Betting could become a pleasurable hobby affording local status and some success. Some cultural theorists have portrayed the workingclass pleasures of cultural consumption as involving a rejection of the mental, embodied in 'cultural forms, activities, symbols, interaction and routinized attitude' ${ }^{27}$ By contrast for at least some men betting was more like the public world of work, with its production and rationality. Late-morning penny editions of sporting papers provided full racing programmes, a summary of other newspapers' tipster forecasts, latest course news, form of expected runners and other useful betting information. In working-class betting overt intellectualism, and the development of systems, even if not necessarily successful, were both socially permissible and actively encouraged. Betting provided an important topic of conversation, and betting theorists see it as a response to budgetary constraints, the irregularity of income through lay-offs, accidents at work or illness, and difficulties of saving. ${ }^{28}$ Even a small amount of surplus income allowed an occasional bet. Betting with small stakes, on a weekly basis, might provide a windfall to spend on a gramophone, a wireless set, an item for the household or a holiday. ${ }^{29}$ Many British believed that betting in moderation was 'a pardonable habit and one that can fairly be reckoned among his amusements'.$^{30}$ For some workers, perhaps a majority, betting was often on doubles and trebles which offered much greater odds against success, but which increased the amount won and provided a cheap physical, psychological and pleasurable excitement.

Most bet only what they could afford, although for those on the margin of poverty the effects of betting could be adverse. For a few it became addictive. Clapson provides cases where betting to excess created financial hardship, poor 
diet and 'lives made miserable by bad-tempered husbands or wives'; Walton notes 'genuinely widespread secondary poverty on Merseyside' as a result of gambling, while Chinn makes clear its potential ill-effects. ${ }^{31}$ Even the unemployed would bet. McKibbin argues that it was a culturally-sanctioned leisure activity. ${ }^{32}$ As one man told one of Rowntree's investigators in the 1930s, he would rather 'have six penn'orth of hope than six penn'orth of electricity'. ${ }^{33}$ The 1923 Select Committee concluded, 'there is considerable evidence to show that men in receipt of unemployment insurance benefit are using it for the purpose of betting; the Welsh unemployed bet, while unemployed in Sheffield simply made smaller bets. ${ }^{34}$ In 1932/3 several witnesses took the view that people receiving public assistance money, the bare minimum necessary for subsistence, were betting. ${ }^{35}$ For the unemployed, a bet provided pleasurable planning, prospects of happiness and potential community status. The Pilgrim Trust argued cogently that their betting was a rare non-discriminatory area giving them as good a chance as anyone. ${ }^{36}$ Their plentiful time could be profitably used for discussion, analysis and decision. In Greenwich, a visiting American sociologist saw betting as a characteristic British interest of the unemployed. Until the first edition of the evening paper came out, some time before noon, they would discuss the chances of horses they might back, then they would return home for dinner. In the afternoon they would go back to keep track of each other's winners, go home to tea, and in the evening boast about or excuse their luck. By forgoing a regular shilling's worth of comfort, the occasional win allowed them a brief climb out of poverty: 'It's your only chance to get out of a 26/- rut. It doesn't happen very often, but think of it when it does'; 'It gets dull living on 30/- with two kids to support ... one of those thirty bob might bring you in a tidy sum'. ${ }^{37}$ Gambling provided a temporary alleviation of their lacklustre lot.

For women too, betting forged mutual solidarity and community links, and was woven inextricably into their social and cultural environment. ${ }^{38}$ Although women bet less regularly and for smaller amounts than men, both interwar government enquiries accepted that women bet to a large and steadily increasing extent. Canon Green believed that betting was very common amongst northern women, both mill workers and 'women in business', some of them even reading the Sporting Chronicle for betting information. ${ }^{39}$ In the mid-1920s in one poor district of Liverpool over 50 per cent of women supposedly had the 'betting habit' ${ }^{40}$ The profound gendering and implicit masculine bias of much cultural analysis has often located women's leisures and pleasures in a private, gossiping, emotive world. ${ }^{41}$ An analyis of their betting challenges such a view. Oral evi- 
dence from the St Helens, Leigh and Wigan areas indicated that women there regularly gambled. Gambling was not seen in the local community as a social and moral threat like drinking or sexual misbehaviour. ${ }^{42}$ Women sometimes organised illegal betting shops in each other's households, which if well organised provided extra income. Here they could enjoy solidarity and excitement without fear of male reproaches. In one York factory, a female worker who took bets from the girls did 'a big business'. ${ }^{43}$ More generally there was a 'considerable increase' in betting amongst women, especially in the mining villages, and in depressed regions like South Wales or the North-east, where, paradoxically, chapel was also a big influence. ${ }^{44}$ Female domestic servants bet in large numbers, and in poorer working-class residential areas bookmakers even sometimes canvassed women's homes.

Many children too were acquainted with following form and placing bets, learning such cultural competences in the familiar settings of the home and street, which continued to be an active public space for recreation. ${ }^{45}$ Children acted as messengers, bringing slips for parents or older siblings. ${ }^{46}$ Glasgow concerns led to the passage in 1928 of an act prohibiting the use of Scottish youngsters taking betting messages. ${ }^{47}$ Children also bet on their own account. The London schoolmistress above found that her pupils, mostly between 11 and 15 years, commonly bet on big races. Four bet more regularly, and one every day. They were aided by shopkeepers, one of whom took penny bets. ${ }^{48}$ A. P. Herbert alleged that this made them 'grow up masters of subterfuge and devoted gamblers. ${ }^{49}$ Some bookmakers clearly employed children as 'runners' and other such spies, although the term 'children' was ill-defined, and probably meant different ages to different observers. Betting was common amongst older working teenagers, whose lack of responsibilities and spare money provided a betting invitation.

How much did people bet and how many were betting? Evidence to the 1932-3 Royal Commission suggested that most betting was small in scale and regular, with stake money varying from $1 d$ or $2 d$ up to $2 s 6 d$ for wealthier working-class punters. Outsiders, brought up on anti-gambling propaganda, found such low figures surprising. When the chief constable of Manchester tried to explain to the Commission that in his view an average of between $6 d$ and $2 s$ a week was bet, the chairman told him, 'it seems an extremely low figure and totally against anything I have ever heard of'. ${ }^{50}$ Joseph Marshall, secretary of the National Sporting League, estimated that about three and three-quarter to four million people engaged in betting in 1923, and the average working man did not lose more than a shilling a week. ${ }^{51}$ The latter may be special 
pleading, but the former is almost certainly an under-estimate. The anti-betting campaigner Perkins estimated in 1927 that about 80 per cent of the working class bet more or less regularly, and McKibbin and Chinn agree on a figure around eight million for this period. ${ }^{52}$

The working classes did not bet with each other. They placed their bets with bookmakers who illegally took cash starting-price bets. Various myths and cultural stereotypes grew up around bookmakers. Reformers demonised them as enemies of the poor, and created and constantly rehearsed dominant negative images. They were caricatured, criminalised and feared as exploitative parasites or social pariahs feeding on the weaknesses and gullibility of working-class communities. Interwar literature provided a famous fictional example in the person of back-yard bookie Sam Grundy in Walter Greenwood's Love on the Dole. The 1923 draft report saw them as a type of infestation, concluding that 'it is intolerable that the streets should be infested with bookmakers and their agents'. ${ }^{53}$ They could also be presented as 'leeches' or 'vampires'. In the Club and Institute Union Handbook club committees were urged to refuse them admission, so that clubs did 'not become the happy hunting ground of the blood-sucking fraternity who prey upon foolish members in search of phantom fortunes'. ${ }^{54}$ They were portrayed negatively in appearance and personality: corpulent, ringbedecked, cigar-smoking, loud-voiced and check-suited, balding and flamboyant characters, who were variously callous and uncaring, seedy and unsavoury, miserly and miserable, villainous and violent, and despicable and rascally. ${ }^{55}$

Recent historical revisionism has challenged such myths, and portrayed bookmakers as small businessmen, popular local figures, far more benefactors than exploiters, giving to charities, and enjoying communal support, central to the informal leisure culture and economic life of working-class communities. ${ }^{56}$ Appearances often belied the stereotype. One Welsh bookie of the 1920s was described as 'lean and tall', with 'long narrow face, small alert eyes', 'long thin legs' and 'soft and engaging voice'. ${ }^{57}$ Bookies sometimes helped people in financial trouble, and most were reliable, honest and generally well-respected, providing what many perceived as an essential community service. They depended on the collaboration of the local community for shelter from the police. The community depended on them to pay up on winning bets, and cheating was commercial suicide. The 1923 Select Committee findings lent some support, arguing that 'the nature of the business requires that it must be carried out with scrupulous honesty'. ${ }^{8}$ Several police witnesses claimed that they had 'never heard a complaint of dishonesty', and that bookies were 'exceedingly honest', or 
at the least 'fairly honourable' to clients. ${ }^{59}$ Wealthier bookmakers were leading community figures, fulfilling a wide variety of social engagements and expected to buy drinks in the pub. In 1932 the chief constable of Manchester accepted that bookmakers 'were rather good to some of the poorer about them', and cited examples of them paying rents or doctors' bills, or giving banners to churches. ${ }^{60}$ Some such comments were in danger of creating a new romanticised myth, of the bookmaker's total innocence.

To punters the local bookmaker was also the opposition, someone to be defeated. If bookmakers were generally honest, it was more than could be said of some punters, and the press reported a variety of punter scams to defraud the bookie. ${ }^{61}$ Bookmakers occupied an ambiguous position in British society, simultaneously looked down on and looked up to, a tension indicated by the 1951 census which located them simultaneously as middling Social Class III, Socio-economic Group Ten (skilled manual workers), and Wage-earner Group $B$ (equating with professional staff).

Actual numbers of 'street' bookmakers are unclear. Estimates from 1923 Select Committee and 1932/3 Royal Commission witnesses, the sporting press and elsewhere varied widely. The 1923 Select Committee was offered estimates of bookmakers ranging from 1,500 to 25,000, including credit and street bookmakers, onlookers and 'runners', yet 14,625 bookmakers actually purchased a licence in 1926, when street bookmaking was still illegal, and street bookmakers had no need of a license. In 1932/3 the number of street bookmakers in London was conservatively estimated as over 750, and in Manchester between 150 and 180, excluding agents or runners. ${ }^{62}$ Religious minorities often went into bookmaking in higher proportions than their numbers might suggest. In Salford many of the leading back-yard bookies were Catholics, and in Glasgow many were Irish Catholics, damned through both religion and ethnicity by anti-gambling Protestants. There were also large numbers of Jewish bookmakers, on the racecourse circuit, in the East End of London, in Birmingham and Edinburgh and probably elsewhere.

Most bookies operated on a relatively small-scale basis, some as family businesses, others with a few workers. Punters brought cash stakes wrapped in scraps of paper carrying details of the race, the horse, stake and nom de plume so that they could remain anonymous. Evidence from 1923 suggests that street bookies took an average of $£ 20$ a day in the summer months, varying with the pitch. ${ }^{63}$ Almost all paid out on starting prices. To avoid paying out too much, many bookies imposed a limit on both the odds and the payouts offered. This ensured that most bets were small. 
Bookmaking could be precarious. Some failed. Contemporary estimates of bookmakers' gross profit varied between 10 and 15 per cent, but street bookmakers often had significant overheads. ${ }^{64}$ Many had to pay for runners, collecting bets on a commission basis, generally ranging between 5 and 7.5 per cent although a new bookmaker might, with some risk, go as high as 10 per cent. Some runners were 'travellers', collecting bets door-to-door or on a round of shops, pubs and works. Milkmen or window-cleaners were suited to the former role. Other runners would have a small block of houses, or small area where everyone knew them. Most large manufacturing industries, shops, shipyards and mines had runners, in fact the 1923 Select Committee quoted figures suggesting any business with over twenty men could support one. The 1932/3 Royal Commission concluded that in many cases employers turned a blind eye to betting on their premises, provided it did not directly affect the work of the factory. ${ }^{65}$ Even ill-educated runners needed to be reliable, and not all were efficient, while some attempted to defraud the bookie. It was possible to take an accomplice's bet after the race and pretend it had been received earlier, and to stop this clock bags were sometimes used, which had to be closed before the race, with the time then recorded on a register. Many bookies also employed lookouts to keep watch for the police. When warned before a police raid, bookmakers often paid people to be arrested on their behalf. They either had to pay fines or bribe police to leave them alone. In some communities like the East End they had to pay protection money. Then again most street bookmakers had days when they lost overall. As a result of such cumulative costs net profit margins were probably quite low, although one bookie's assessment of around 2.5 per cent gross was almost certainly special pleading. ${ }^{66}$

Bookmakers employing runners usually had some sort of base, an unofficial 'office', where winnings could be paid out as paying out was not illegal. A few 'house' bookies used their own homes; most rented a room elsewhere, a powerful incentive for poor families. Paying out was sometimes at well-recognised 'pitches', street areas which they saw as their own territory, although these were by now more commonly used by runners. As public phones became more widely available, trusted runners could clock-bag the bets, phone bookmakers directly to get the results and runners, and pay out after each race on the basis of carbonised copies. In Glasgow, this method, called 'shovel' betting, was commonplace by the 1930 s.

Most working-class communities, especially in poorer urban areas, had street bookmakers or runners. There were also occasional public betting grounds, like the Market Place in Chesterfield or the 'Wag Back' in Blackburn. 
Establishing and defending one's 'pitch' was difficult. Pitches could be back lanes, as in Tyneside or Wearside, street corners as in much of London or Liverpool, or courts and passages, yards and alley-ways. New 'bookies' bought an existing territory, took over a vacant pitch or set up a new one on fresh territory. Territorial battles, where a bookmaker infringed someone else's pitch, or took custom from longer-established businesses, were rarely conducted amicably, although they were sometimes sorted by the police to maintain order. Green gave one instance where an existing bookmaker complained to the police, who started arresting the new man's runners, telling him, 'We don't mean to have you cutting in on Pete's ground'. ${ }^{67}$ Chinn admits that most bookies were 'hard' men. ${ }^{68}$ Defending territory, and dealing with difficult punters, they needed to be.

Differences in location depended both on local custom and police attitudes to enforcement of the betting laws. Many bookmakers used public houses, since if a bookmaker used premises without the knowledge and consent of the licensee or staff he could not be convicted. This forced police to observe for longer, making policing more costly and offences more difficult to prove. In 1923 a superintendent detective of police estimated that between 100 and 150 public houses were used for betting in the City of London alone. ${ }^{69}$ The pub exploited the key relationship between betting and sociability, since big winners often stood a round of drinks. In Bolton betting and sport accounted for 29 per cent of all conversations observed by Mass Observation. Betting and booze, camaraderie and conversation interacted well. One leading Bolton pub bookie, who employed about 170 runners, went round the public houses where his agents were employed, buying drinks. As a prestigious local celebrity he was expected to contribute to annual picnics or bowling handicaps, while his agents facilitated money lending. As one local landlord admitted freely, 'a good bookie is a great asset to a pub' ${ }^{70}$ In the North-west of England, Yorkshire and Wales working men's clubs were another common locus of betting activity throughout the period, as were Conservative clubs and billiard halls. ${ }^{71}$ In Oldham in 1923, some fourteen clubs were supposedly used by a majority of betters. ${ }^{72}$ Pubs and clubs of many kinds were havens of resistance to anti-betting views, just as churches were havens of support.

Clubs were alert to betting custom in other ways too, and a credit totalisator, a machine pooling all bets, was being used in London by June $1923 .{ }^{73}$ By the early 1930s commercial 'Tote clubs' were proliferating in towns and cities throughout Britain, often on a cash basis after a favourable House of Lords judgment making betting facilities available all day. About a quarter also sold 
alcohol, and up to 2,000 people thronged a single Baker Street Tote Club. Membership fees varied from $5 s$ to a penny. By December 1932, there were approximately 250 clubs in England and Wales, and they were increasingly creating a moral panic. Reversing the judgment in the spring of 1933 allowed widespread prosecutions of clubs in London, Birmingham and Manchester. They were made explicitly illegal by the 1934 Betting and Lotteries Act. ${ }^{74}$

Illegal bookmakers were found everywhere, even at the heart of the London establishment. In 1921 a War Office clerk and an Admiralty electrician were prosecuted for running a book in the Household Cavalry Brigade canteen. They had 108 slips in their possession. ${ }^{75}$ Small shopkeepers, such as barbers, tobacconists, confectioners, greengrocers, butchers or newspaper sellers, generated increased profitability by taking cash bets. This may well have drawn in more female bookmakers. At Middlesbrough, for example, the Normanby general dealer Annie Round was prosecuted for taking some sixteen bets in her shop between 12 noon and 2 p.m.; Rosie Pickering, a popular Birmingham bookie, owned a fish and chip shop. ${ }^{76}$

In those areas where street betting was common, the law's perceived inequality produced resentment. Although there were working-class people who objected to betting, bookmakers were usually sustained and supported. Police witnesses unanimously told the 1923 Select Committee that 'the sympathy and active assistance of the general public in the neighbourhood is with the bettor, whether bookmaker or backer, and against the police'. ${ }^{77}$ This eroded police-public relations in working-class communities. The evidence to the 1928/9 Royal Commission on Police Powers and Procedures made very clear that the laws were 'out of harmony with public opinion'. The betting laws were regarded as 'class legislation', and enforcing them created 'a distinct worsening of relations between the police and the public'. ${ }^{78}$ In fact, as Dixon points out, working-class community attitudes were hostile to the law more generally, and he argues that this period was one 'in which class-discriminatory prohibition was at its zenith'. ${ }^{79}$ For working-class punters bookmakers were the opposition, but they were part of the local community and once the police were involved perceptions shifted.

Senior police attitudes were ambiguous. Most felt, with Trevor Bigham, the assistant commissioner of the Metropolitan Police Force, that the law was 'inadequate, obscure, illogical, and ineffective' ${ }^{80}$ It placed heavy demands on police time and budgets. In 1923, Liverpool alone employed twenty-eight full-time anti-betting officers, costing far more than the fines they raised. ${ }^{81}$ Some policemen wanted more severe punishments, and condemned betting. Others 
felt that even prison sentences would have little effect. Superintendent Denton felt, with pardonable hyperbole, that 'it has such a hold on the people today. Even if they made it a penalty of two years it would have little effect' ${ }^{82}$ Officers complained that bookmakers organised lookouts and escape routes, and observed, corrupted and bribed policemen. They complained too of very varying attitudes by magistrates. ${ }^{83}$ Police disenchantment with the prohibition strategy increased through the 1920s. It was exacerbated by the ill-fated attempt at the imposition of betting duty in 1926. By 1932 the police concluded that at best their actions merely restricted the volume of betting and acted as some deterrent. $^{84}$

Even high levels of prosecutions had little impact. They were costly, and harmed consensual policing. Consequently, many forces tackled street betting irregularly, usually following press or written complaints or on a ritual annual level. Alternatively, betting was moved from place to place, a form of social zoning. In Blackburn, police prosecuted street betting but left club betting alone. ${ }^{85}$ Elsewhere illegal betting shops or street betting in areas well off the main streets would be allowed. By 1932/3 the Committee of Chief Constables would have preferred to see legalised betting shops and licensed bookmakers to aid control. ${ }^{86}$ Betting in shops, pubs or other premises was much more accepted by the police in Scotland, the North of England and Northern Ireland than in the Midlands and the South. Enforcement became a matter of practicalities. When, where and how the 'offence' was being committed and by whom determined whether it was to be overlooked, suppressed or harassed. The activity was often connived at by the police in order to maintain control, with informal arrangements widespread, and betting regulated by payoffs and ritualistic setup arrests. The arrival or departure of a keen anti-betting superior officer, or eager officers seeking promotion, and varying levels of complaints, all affected prosecution levels. In York prosecutions dropped from 165 in 1936 to only 5 in $1937 .{ }^{87}$ In racing Newmarket it was claimed that the police 'turned a blind eye as much as they could', and 'the magistrates were lenient'. ${ }^{88}$

Widespread allegations of corruption challenged the powerful myth of the police as having a special relationship with the public based on shared values and assent to British law. Some complaints were probably unfounded, others were attempts by bookmakers to get rid of over-zealous anti-betting officers. Some were true. Street betting offered a serious temptation to the police, not least because many policemen bet. Dixon suggests that 'until 1960 police-bookmaker relations of varying degrees of impropriety were normal practice' ${ }^{89}$ Both sides gained. The bookmaker avoided dislocation of business, 
or getting key staff arrested, by putting up well-paid stooges. The police either increased their untaxed income, or arranged arrests with full confidence of convictions, improving their prosecution record. Senior officers thus faced adverse press publicity from righteous anti-gamblers about police corruption, and had to claim that it was rare or infrequent. With public opinion divided, the police could never win. If they tried to enforce the laws they damaged police-public relations. If they did not they were accused of laxity, corruption or both.

\section{Betting and the middle classes}

Modern historians and the interwar establishment both presented the middle classes as having rarely bet on sport. ${ }^{90}$ The Report of the 1932-33 Royal Commission stated that betting among the 'more well-to-do classes' had been decreasing, a decrease earlier claimed in evidence given to the Select Committees of 1902 and $1923 .{ }^{91}$ Such perennial 'decreases', based on police and credit bookmaking evidence, helped to maintain the myth of middle-class respectability. The police knew little of middle-class betting because of its credit legality. Credit bookmakers only knew their own business. In the early 1930s, following the world-wide depression and drop in disposable income, credit bookmakers claimed a considerable decrease in custom, suggesting that in some cases turnover was 'only half of what it was a few years ago' ${ }^{92}$ Much of this, however, was probably a reduction in the size of individual bets rather than the number of people betting, although Ladbrokes found it somewhat more difficult to obtain new clients in the 1930s than they had in the 1920 s. $^{93}$

In reality there was a significant middle-class betting market. The 1923 Select Committee on Betting Duty concluded that 'practically every class bet'. The more detailed evidence supports this view. The chief constable of Liverpool claimed that betting was widespread 'amongst all classes in the community'. Even Canon Green believed that there had been an increase in betting 'among the middle-class people', citing one better-class office where each betting worker was 'either a public school man or a 'varsity man'. Street bookies were found in the West End as well as the East End, according to the assistant commissioner of the London Metropolitan Police District. Commercial travellers placed bets with 'boots' in hotels. Most of the clients of credit bookmakers were drawn from the upper and middle classes. Evidence suggested that 'the majority of people of standing, business people especially, prefer to open an account', and credit firms usually expected bank details or other forms of 'sporting' references. 
Further direct evidence of middle-class betting surfaces in court cases, newspaper reports and oral testimony, even though the patterns of middle-class social communication concealed it more easily, with bets placed by phone or managed through the post. We learn of middle-class betting accidentally, as when a particularly big winning bet became known locally. An article fondly reviewing the life of the seaside theatrical entrepreneur Billy Scarrow, for example, listed some of his experiences and then said that 'better still will his good fortune in backing "King of Clubs" when it won the Lincoln at 100-1 be remembered'. ${ }^{94}$ Such references are almost certainly a large under-estimation. The prospects of the Derby or Grand National were a major topic of conversation in social contexts such as gentlemen's clubs, the Stock Exchange or even the barber's shop. One 1937 cartoon illustrates this latter point well. A barber is being dismissed from what is clearly a high-class establishment, with another of the staff saying confidentially, 'The Guv'nor just HAD to sack the fellow. He hadn't a tip for the Derby'. ${ }^{95}$ Clerks also found betting appealing, sometimes using runners or street bookmakers. Many of those using the betting pubs in the City of London were clerks. ${ }^{96}$

The clients of credit bookmakers also surface in oral testimony. One woman credit bookmaker, advertising herself as 'London's only lady bookmaker', had clients who were accountants and actresses, mayors and manufacturers, publicans, stockbrokers, tradespeople, shopkeepers, company directors and insurance agents, and her daughter claimed that 'even neighbouring bank managers, whose terms of employment were supposed to veto any form of gambling, would ring up on big race days'. ${ }^{97}$ Sometimes, too, betting was an apparent contributory factor to newspaper-reported middle-class crimes such as fraud, where bank clerks or other middle-class employees used funds in attempts to recoup betting debts. Such cases undoubtedly contributed to betting being perceived as unrespectable amongst some middle-class groups.

Middle-class betting could be found both inside the racing world itself and amongst the wider betting public. For some betting began at grammar school or public school. ${ }^{98}$ Inside racing many owners and trainers backed their own horses when they fancied they had a chance, while there were also a few plungers, betting $£ 10,000$ or $£ 20,000$ in a day on the course, although most racing commentators felt that the number of heavy gamblers was in rapid decline, and increasingly few bookmakers would lay the odds to such amounts. ${ }^{99}$ Information about horses' progress provided by the press limited opportunities for betting coups. Bookmakers were also far more careful not to bet excessive odds, and larger bets immediately reduced them. Plungers 
inevitably failed, and the MP Horatio Bottomley may well have lost $£ 1$ million over his horses. Those middle-class gamblers who did get into debt were targeted by carefully-phrased advertisements for private loans: 'Sportsmen deal with sportsmen. How humiliating to be refused by a pal or your bank. We are here to obviate that. A chat, a smoke, a drink (if you like) and an open cheque'. ${ }^{100}$

Most 'professional backers' were middle-class either by origin or by previous occupation. The former racing correspondent Archie Falcon, who was friendly with betting owners such as Bob Sievier and trainers like the Newmarket trainer John Watson, was very successful in the early 1920s, and reputedly 'worth a quarter of a million' in 1923, although some major losses thereafter, failure of his stud, and a bad Stock Exchange run, reduced his capital to some $£ 20,000$ when he retired. ${ }^{101}$ Another middle-class backer, Charles Beaty (d.1931) left $£ 189,000$. Geoff Harbord, the son of a clergyman, formerly in the Horse Guards, was also highly successful. ${ }^{102}$ Middle-class social skills developed good contacts to supplement observation of form. Although the 1923 Select Committee felt the professional backer group had 'grown up in recent years' this was an ahistoric view. They had existed throughout the nineteenth century. Given the increased volume of racing information, the speed of communication and the well-organised bookmaking system, their task was actually becoming more difficult. Alfred Heathorn, a Piccadilly bookmaker, conceded that a professional backer could hold his own, if he had good knowledge and judgement of form. ${ }^{103}$ To have any chance of success they needed large amounts of capital, since they were certain to have losses as well as wins. One professional backer at Ascot supposedly placed bets amounting to $£ 60,000$ during the day but only won or lost $£ 100 .{ }^{104}$

Although the proportion of betters amongst the middle classes may have been lower than that amongst the working classes, the actual numbers involved in the wider middle-class betting public must still have been quite significant. Credit firm numbers provide a useful surrogate indication of middle-class involvement, especially since, as even Green conceded, there was 'very little credit bookmaking amongst the working class' ${ }^{105}$ Credit betting was available right across Britain's larger towns. In South Wales alone, for example, as early as 1921, the Turf Guardian Society listed credit bookmakers in Abertillery (1), Bargoed (2), Cardiff (15), Chepstow (1), Llanelly (1), Neath (2), Newport (7), Pontypridd (1) and Swansea (6). ${ }^{106}$ In 1923 the assistant commissioner of the Metropolitan Police estimated that there were about 800 credit bookmakers in London. In Liverpool the chief constable estimated that there were over 250 
legal offices, 'exceeding strict' in the way they carried out their business, and 'well-conducted'.

How many clients were there? Walter Randall, a wealthy credit bookmaker, and secretary of the Turf Guardian Society, formed in 1918, which had both layers' and backers' sections, estimated that there were about 2,000 credit bookmakers in Britain. If this is correct, middle-class punter numbers can be estimated from figures offered to the 1923 Select Committee by the secretary of the National Sporting League. On his calculations, based on systematic enquiry, each credit bookmaker required an average of 250 clients to make a living, thus suggesting 500,000 clients. But some clients will have had accounts with more than one bookmaker. A proportion of clients would have been upper-class, and a few others artisans, who could sometimes get accounts if they could prove that they were given credit by coal merchants or shopkeepers. ${ }^{107}$ Some credit offices also laundered a substantial amount of cash betting. Even so this suggests a substantial upper- and middle-class betting public, rendered credit-worthy through wealth, income and status, who could bet by letter, phone or visit.

More positive middle-class attitudes to betting are also to be seen in the ways some magistrates dealt with betting prosecutions. Some bet themselves. The Church Times expressed the view that 'the magistrate who imposes a fine in his court for street betting, may ... as likely as not, have his own credit account running with a firm of bookmakers' ${ }^{108}$ Many court proceedings were fairly ritualistic, and betting offences were clearly not looked upon by most magistrates as real crimes. Many magistrates were very reluctant to give a conviction at all. Where bookmakers had been arrested three times, thus qualifying for a large fine or imprisonment, many magistrates avoided using imprisonment as punishment or deterrent. The 1923 Select Committee was told that in Liverpool, men were 'never' imprisoned for a third offence; a Glasgow bookmaker felt imprisonment was 'very rare'. 109

Off-course credit bookmaking firms were often large enterprises. McLeans, one of the largest starting-price bookmakers in Scotland, in 1923 had a staff of sixty, rented thirty telephone lines, and took an average of three hundred telegrams and $\mathfrak{£ 5 , 0 0 0}$ in bets a day. ${ }^{110}$ The 'Douglas Stuart' firm employed over a hundred, with twenty answering the phones (in pairs to prevent fraud) and decoding telegrams, twenty checking telegrams and phone slips against results, ten opening letters, five people in accounts, and fifteen typists, as well as filing, printing and other workers. It sifted its clients carefully and had few bad debts. ${ }^{111}$ Most big bookmakers advertised for clients through the racing press. David Cope Ltd, for example, regularly requested clients to 'send your name 
and address, in confidence, if you would be interested to receive particulars of our service. Every class of bet is catered for, at Ante-Post or Starting Price, or at Totalisator Odds if desired. All transactions are treated with the privacy that attaches to banking. Daily or Weekly Credit Accounts are opened'. ${ }^{112}$

Many credit firms were long-standing, in business from well before 1914. Like the street bookmakers, they were generally highly honest, though there were occasional examples of swindlers who set up a bogus betting office, took bets, then failed to pay. ${ }^{113}$ The London region clearly dominated, with Lancashire the leading provincial region. Larger firms increasingly had several branches. Scotlands, for example, claimed by 1938 to be 'the largest bookmakers in the world', with ' 106 branches throughout the country. ${ }^{114}$ The wording of advertisements gave a clear insight into the factors appealing to customers. Such factors included reputation for honesty, fair dealing and integrity in meeting obligations and dealing with clients, the length of time established, their high status and tone, and whether or not they had limits on the amounts bet. Positive press comments were also quoted. Smaller firms could be started up with relatively small capital. A dispute between two bookmakers carrying on a phone credit business at a London flat showed they had each put in $£ 200$ and were making an average $£ 20$ weekly profit. ${ }^{15}$

Some office bookmakers, including Littlewoods with its football pools betting, acted as credit bookmakers and also sometimes illegally took money in advance by post for horseraces. This was more common in Scotland, where firms specialising in ready-money postal betting had long been established in Glasgow and Edinburgh. They took bets from throughout Great Britain. Up to 1925 a High Court judgment had not allowed sealed letters to be opened if a bookmaker's office was raided, but this then changed. In Edinburgh bookmakers' offices were raided annually by the police, and fines of $£ 100$ were levied. This was a symbolic act, since their activities were very well known. Any reader of the sporting papers would know what their advertisements really meant. Some firms invited 'letters'. Others had an 'industrial branch' in Scotland. Yet others gave an English address for credit, 'otherwise' a Scottish one. Some offered very limited credit, where clients paid a deposit and got credit of up to twice the amount sent in. As evidence to the 1932/3 Royal Commission indicated, the Post Office had to have special vans for deliveries of postal bets because of the volume of the Scottish bookmakers' business. ${ }^{116}$

Anti-betting groups firmly believed that bookmakers made excessive profits, but credit bookmakers often had bad debts. Small credit bookmakers with limited capital were most at risk. Frederick Stringer, for example, a successful street 
bookmaker through the 1920s, turned to credit bookmaking in 1934 but found himself bankrupt by 1935, 'a considerable number of bad debts being incurred'. ${ }^{117}$ Ladbroke and Co., one of the largest firms, employing forty or fifty clerks on Fridays just to balance and send out accounts, estimated in the 1920s that about 12.5 per cent of credits were bad debts. They had a very large number of $1 s$ and $2 s$ bets, but other bets could be substantial. ${ }^{118}$ In 1932/3 one witness saw bad debts as 15 per cent of the turnover. ${ }^{119}$ So overall gross profits were not excessive. The 1923 Select Committee estimated that net profits on turnover, while varying with the type of business, were about 3 per cent overall. Munting sees this as an under-estimate, but one 'not too far off the mark', citing similar figures from later in the century. ${ }^{120}$

To improve profits bookmakers often tried to increase turnover by offering commission for bets passed on to them by smaller firms or individuals, although quoted rates vary widely, from 1.25 to 10 per cent, and bookmakers may not have been prepared to give away such confidential business information. ${ }^{121}$ These small 'commission agents' sometimes started by taking bets from friends, local business men or acquaintances and passing them on, profiting from the commission. Some of these themselves then set up in business, installed telephones and opened accounts with a number of credit firms.

Top bookmakers could accumulate substantial wealth, though the number of such earners was few. Usually their high earnings reflected a smaller but often very wealthy clientele, an increased risk, and sufficient capital to lay and sometimes lose large amounts. When Joe Pickersgill, the Leeds bookmaker, died in 1920 , his will was proved at $£ 746,459$, while George Herring (d.1915) left $£ 1,371,000$. Another London bookie, William Howett, died in 1924 worth $£ 102,737 .{ }^{122}$ Some bookmakers started as backers, or as street bookmakers, others as bookmakers' clerks. Harry Slowburn, initially a clerk, set up on his own in the early twentieth century and was friendly with all the leading owners and trainers. He left more than $£ 100,000$ on his death in the 1940 s. ${ }^{123}$ At the other end of the scale, while the odds were in favour of the bookie in the long term because of the way odds were calculated, in the short term a combination of several bad debts and a run of punter successes could mean bankruptcy.

Bookmakers were usually well organised, managing disputes, dealing with defaulters, or increasingly lobbying Parliament. The Rules Governing Betting were controlled by Tattersalls' Committee, which had dominated the settlement of betting disputes nationally since its incorporation of the Newmarket Rooms Committee in 1899. Bigger bookmakers increasingly had their own organisations, including the Bookmakers' Protection Association (BPA). First 
founded in 1921 in the South of England, largely in response to the course 'protection' and extortion gangs of the period, this became the National BPA in 1932, with its own publication, Banyan, circulated privately. ${ }^{124}$ Other organisations with significant bookmaker membership included the Victoria Club, the National Sporting League and the Turf Guardian Society. The Victoria Club in London was the centre of the ante-post betting market, the first odds offered well before major races, with quick-fire transactions done by word of mouth across a billiard table, with horses backed to win $£ 250,000$ or more. It provided the first press-published odds. Here, and in other homo-social sporting clubs such as the Beaufort Club, such betting was seen as 'enormous'. ${ }^{125}$ The National Sporting League was more political, arguing for the legalisation of betting and putting pressure on politicians to support the racing industry. The Turf Guardian Society was dominated by larger bookmakers, who wanted bookmakers to play the key role in looking after turf interests. ${ }^{126}$

\section{Sweepstakes, luck and British culture}

Working-class betting rationality was usually partial. To bet rationally a better really needed information about the likely starting price. Unfortunately even in 1931 only a minority of the daily regional and national press published forecasts of future odds. Major circulation evening papers like the Evening Standard or the Manchester Evening News did not carry them. Equally the jockey was important, but papers only rarely provided lists of probable riders. Only the specialist racing press provided the full details of previous form punters required. To that extent punters were betting blind. The various so-called systems, such as following a leading jockey, or backing favourites or second favourites, all lost money in the longer term if followed consistently, as the sporting press regularly demonstrated. ${ }^{127}$ Some attempts to cash in on the vogue for systems, such as The System-Workers' Gazette: Organ of the System Workers' Association: A Monthly Review Devoted to Systematic Turf Investment, published in Bournemouth in 1922, lasted only a few months, but the Racing Library in Manchester specialised in reprints of famous betting systems and continued through the 1920s.

Some more impulsive betters made their selections according to luck and chance, although there is no means of identifying the proportion, and the rational and irrational merged together in the several books published between the wars with titles that suggesting astronomy/astrology could help pick a winner. ${ }^{128}$ In one further betting form, the sweepstakes, reliance on chance was even clearer. While a successful long-odds winning double simply provided a 
temporary windfall and pleasure, winning a huge prize sweepstake, with far longer odds stacked against it, could be a life-changing experience, something both the working- and middle-class family could usually only dream about, a subject of radio, pub, film and family fantasy. Cultural analysis of pleasure has identified fantasy as a key driving source of motivation, ideologically enabling people to symbolically or potentially gratify specific needs not met in real life. Others have seen it as a form of resistance to economic and social pressures, entailing a playful and enjoyable way of transcending reality. ${ }^{129}$ Both arguments applied to social life between the wars, and the grand fantasy of a large sum for a small one was a powerful motivator. Sweeps were an irrational form of betting. Tickets could cost 10 s or $£ 1$, and winning was reliant on chance since only a very few purchasers drew runners, and the big prizes went to those who drew the winner and placed horses. But as the lucky city workman who drew the favourite in a Liverpool sweep explained, 'it was a bit of a push raising ten shillings, but I felt my luck would come off'. ${ }^{130}$

Sweeps were technically illegal, but, like the football pools, they were a hugely popular cultural form between the wars, thanks at least in part to economic uncertainty and the coverage the daily press gave to their large prizes. Even the unemployed could buy an annual sweepstake ticket. Sharing in the widely held social dream of having a large sum of money, changing one's life and perhaps moving up in status was highly attractive. The 1923 Select Committee referred to the 'extra-ordinary recent growth of sweepstakes' in its report, and while it provided no quantifiable evidence to support this view, the commonality of references to sweepstakes seems to confirm it. ${ }^{131}$

Racing sweeps operated right across the spectrum of class, and could be organised by high-status groups, trade unions, popular charities or publicans. Some sweeps were organised abroad. Just after the war the Calcutta Turf Club had the leading sweep with three prizes of $£ 75,000, £ 35,000$ and $£ 15,000$ for the top three Derby horses. The Dublin bookmaker Richard Duggan regularly ran a $£ 25,000$ Derby sweep in the early 1920 s 'in aid of the Meath Hospital, Dublin', depositing the prize money with the editor of the Sporting Life, and the Sporting Club of Monte Carlo had a first prize of 222,592 fr. for its Grand National sweep. ${ }^{132}$

The involvement of the British financial world and clear evidence of middleclass approval can be seen in the high prizes offered by the supposedly private but widely available London Stock Exchange Members' Mutual Subscription Fund ( $£ 25,000$ first prize) and the Baltic Exchange Sweep $(£ 10,000)$. As the subscriptions for the Stock Exchange Sweep rose ever higher, reaching $£ 1$ million in 1929, 
there were increased anti-gambling complaints. In the 1920s Liverpool had a Liverpool Exchange Newsroom Sweepstakes open to the public, and a separate private one involving 'well over $£ 2,000$ ' for the Cotton Association and their friends. ${ }^{133}$ By 1930 the Cotton Exchange Mutual Subscription Fund offered a first prize of $£ 16,000$ for the owner of the ticket with the winning horse for the Grand National; second and third got $£ 2,500$ and $£ 1,000$ respectively, all finishers got $£ 200$ and other horses starting $£ 100$. Over 70,000 10 s tickets were sold. Organisers of sweeps covered the political and social spectrum. In 1924 such diverse organisations as the Actors' Association in Liverpool, Bootle Trades Council and Labour Party, Caversham Constitutional Club, Kingswynford Divisional Labour Party and Otley Conservative Club were prosecuted. The racing establishment organised sweeps at the H. B. Club, or the Derby dinners. ${ }^{134}$ Works, public houses and even families often organised their own. The Otley Bowling Club in Yorkshire ran a large, very successful $10 s$ Derby sweep despite regular police prosecutions in the 1920s, before winding up in 1932.

Prices and organisational involvement both show that sweeps were attractive to the middle classes. A Daily Mirror cartoon, entitled 'You can't keep out of sweepstakes', shows two men, clearly contextualised as middle-class by clothing and room furniture, such as office stool and bureau, discussing sweeps. One intent on selling yet another sweepstake ticket opens by asking the other if he is in many sweeps this year. The other complains that he has been in 'at least ten each year for thirty years and never drawn a horse'. The other extends his sympathy over the next three frames, telling him he is 'right to keep out of them', is 'very strong-minded', and that 'this sweepstakes business is abominably overdone', before getting to the sales pitch, telling him he 'mustn't miss this one quite a small affair - you're bound to draw a horse'. ${ }^{135}$ That The Times always printed the names of lucky drawers assumes reader interest. Buying a ticket was part of the ritual preceding leading racing events, although different race sweeps had a somewhat different regional distribution. St Leger sweeps, for example, were particularly popular in Yorkshire. ${ }^{136}$

Sweeps fulfilled a variety of social needs. Many who otherwise never bet took part. Sweep promoters generally acknowledged that as many women as men bought tickets. Purchasers came from all walks of life. Purchase was often a highly social joint activity, sharing the investment, the risk and the excited anticipation, and was deeply rooted in associational forms like the public house, the workplace or the family. The Derby Irish Hospital Sweepstake of $1933 \mathrm{had}$ inter alia 'thirty engine fitters', 'the four doms', 'fourteen villains', 'ten good pals', 'four old pals', 'ten wise crackers', 'five hard-ups', 'the tennis workers club' 
and 'weneedit'. ${ }^{137}$ A contemporary described how 'newsboys dash frantically though the streets, selling their papers giving alphabetical lists of owners. Their supply is immediately exhausted, as men, women and children leave their jobs, whatever they may be, buy papers and eagerly scan their lists'. ${ }^{138}$

The police had real difficulty in responding. Stopping sweeps alienated the public and caused paperwork. Law enforcement appeared anti-social, or even, considering the popularity of sweepstakes for Britain's big races among British expatriates and colonial administrators, anti-Empire. Generally forces only acted if a complaint was lodged, or questions were asked in the press or Parliament. Then the promoter would be told to abandon the scheme, thus avoiding policework. Quite often however the promoter would continue. Magistrates' attitudes depended very much on circumstances and personal attitudes. Fines for organ-

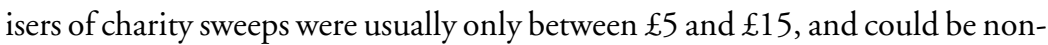
existent. ${ }^{139}$ In Greenwich, police prosecuted the Printing and Kindred Trades Blind Aid Committee, run by men 'held in highest esteem', who had a sweep on the Manchester Handicap. It had raised $£ 25,000$ for blind institutions over five years, and the 1932 sweep raised $£ 4,700$ gross, with clerical expenses of $£ 200$. Prizes were of $£ 380$. The rest went to the charity. Here the magistrate said the lottery was illegal, but dismissed the summons on costs. ${ }^{140}$

Government concerns about money in Britain being invested in large foreign sweepstakes first resulted in police warnings in 1921, when the Post Office returned illegal remittances to their senders. ${ }^{141}$ Parliamentary irritation strengthened in 1930 with the introduction of the Irish Hospitals' Trust (IHT) sweeps, again promoted by Richard Duggan, partly for the benefit of Dublin hospitals, but overtly supported by the Free State government. ${ }^{142}$ These were successful in Ireland, but more successful still in England, even with 10 s tickets. They were attractive to ticket sellers because the IHT promoters paid a sellers' commission of about $£ 1$ on every $£ 6$ of tickets sold, and gave sellers' prizes too. Money flooded out of Britain to benefit the recently created Irish Free State. At its peak it was a regular flutter for around five million people in Britain alone, with a further two million in the Irish Free State, the USA and Commonwealth, buying tickets in bookmakers' offices, pubs, clubs and shops. The 1930 draw was on the Manchester November Handicap, with a first prize of $£ 100,000$. Later the three draws each year focused on the Grand National, the Derby and Cesarewitch. In total, the first eight sweepstakes generated about $£ 27,000,000$ in subscriptions, with about $£ 18,500,000$ coming from Great Britain. Of those who drew a horse, about 60 per cent usually had English addresses. ${ }^{143}$ The success of the IHT sweeps adversely affected British sweeps. The April 1931 Stock 
Exchange prizes dropped to $£ 15,000, £ 6,500$ and $£ 1,400$ and 100 runners-up prizes of $£ 150$. It had become a quasi-private sweep once again, supported by Stock Exchange employees and their friends.

The British government saw the sweeps as a fiscal drain, benefiting the Irish Republic. ${ }^{144}$ They attempted to prevent the entry of advertisements and tickets and the sending of money, and prosecuted English agents, strategies which they were already applying to other foreign lotteries, but agents received only nominal penalties in the courts. In 1933 the prime minister reacted to news of a slight fall in receipts by saying, 'I am glad of that. I hope that the next one will produce nothing at all'. ${ }^{145}$ The measures the government could take also alienated public opinion. A Strube cartoon pointed out that a man could bet at greyhound races, phone a credit bookie, back horses on the Tote, invest on the Stock Market, or play for money in his home, 'BUT when he buys a sweepstake ticket for the good of the hospitals, THEN THE LAW STEPS IN - Which is absurd'. ${ }^{146}$ What seemed equally absurd was that an attempt, supported by the Duke of Atholl, to launch a British equivalent in aid of British hospitals, with nine million tickets, and large prizes, was quickly stopped. ${ }^{147}$ As we saw earlier, a large part of the 1932/3 Royal Commission was devoted to gathering evidence on the operation of the lotteries, especially the IHT sweeps, and the 1934 Lotteries and Gaming Act made greater legal provision for charity and sporting club sweeps, while prohibiting the advertising of foreign lotteries, the sending of tickets through the post, and buying such tickets. IHT sales dropped thereafter.

\section{Conclusion}

Gambling is a powerful theme in social and cultural history. Racing and betting went together in terms of their wider cultural significance, and this chapter has focused on the extraordinary popularity and resilience of betting not just in working-class culture, but also, albeit in different forms, across the other classes. The extent of credit betting challenges the view that middle-class betting was negligible, while the sweeps were a further form of middle-class participation in the betting world. One hitherto singularly under-explored theme in broader historiography is the extent to which the middle classes found cultural contexts in which to be naughty was nice, and in which the excitements, anticipations and pleasures of activities like betting could be safely enjoyed.

Within the working classes, the government prohibition of cash betting, and police efforts to curtail its spread, were defied, skirted round or ignored by the 
betting population, who could be found across the boundaries of age and sex. Its powerful prevalence in the face of a pervasive climate of disapproval and repression in the churches and other respectable contexts showed betting's strong resilience. Even the unemployed bet. This chapter has shown how for the vast majority of punters, gambling was simply a pleasurable recreation characterised by self-regulation, a reasonably rational approach and a measure of selfassertion. Many bet regularly, but modestly, and a very limited proportion of the personal or family income was involved. Such general moderation undermined all attempts to marginalise gambling. This chapter has also stressed the important extent to which betting was a social activity, enjoyed communally, and found in both work and leisure contexts, with bets placed in private houses and shops, the pub and Tote clubs.

It has also shown the extent to which bookmaking was a formal and highly commercial activity. Numbers involved were unquantifiable, although an estimate in the Economist in 1936 of 66,000 people directly dependent on bookmaking, plus many other part-time agents, is regarded by Chinn as 'plausible'. ${ }^{148}$ Different perceptions of the role of street bookmaker in workingclass society have been explored here in order to illustrate the complex roles they played. Previous work has tended to underplay the importance of credit bookmakers in sustaining middle- and upper-class betting. McKibbin, for example, ignores it, while over-stressing more rational approaches to betting. This chapter has balanced such views with a renewed emphasis on the importance of chance as well as rationality, most encapsulated in the fantasy of the lifechanging win on the big sweepstakes. Between the wars, at a time of economic uncertainty and widespread distress, the sweeps played an important part in maintaining a mood of optimism and hope. A big win offered the prospect of escape from all difficulties, a prospect which the more rational, small-scale betting and the temporary alleviation of a small win could never achieve.

\section{Notes}

11923 House of Commons Select Committee on Betting Duty, minutes of evidence QQ8722-59.

2 Roger Munting, An economic and social history of gambling in Britain and the USA (Manchester: Manchester University Press: 1996), p. 198.

3 Ibid., p. 171; David Dixon, From prohibition to regulation: bookmaking, anti-gambling and the law (Oxford: Clarendon Press, 1991), pp. 187-8.

4 Mark Clapson, A bit of a flutter: popular gambling and English society c. 1823-1961 (Manchester: Manchester University Press, 1992); Munting, History of gambling; 
George Harris, 'Street betting in the twentieth century: its social significance in the working-class Community', Unpub. MA diss., University of Lancaster, 1978.

5 John Stevenson, British society 1914-45 (Harmondsworth: Penguin, 1984), p. 386.

6 The Pilgrim Trust, Men without work (Cambridge: Cambridge University Press, 1938), pp. 98-100.

7 Munting, History of gambling, pp. 172-3.

8 R. Stone and D. Roe, Measurement of consumer expenditure and behaviour in the UK 1920-1938 (Cambridge: Cambridge University Press, 1954), pp. 91-2.

9 B. Seebohm Rowntree, Poverty and progress: a second social survey of York (London: Longman Green and Co.; 1941), p. 403.

10 Munting, History of gambling, p. 94.

111923 Select Committee, QQ7401-11, 7417 (J. Lee); Appendix IIIA Metropolitan Police Convictions; p. 593, Evidence of Inland Revenue; QQ813-19 (Caldwell); Q1335 (Bigham); Q7152 (Green). Draft report para. 26.

121923 Select Committee, Q7354 (Lyttleton).

13 Carl Chinn, Better betting with a decent feller: bookmaking, betting and the British working class, 1750-1990 (Hemel Hempstead: Harvester, 1991), p. 165; 1923 Select Committee, Q4118 (Randall).

141923 Select Committee, QQ1153-4. Dixon, From prohibition to regulation, p. 187.

151923 Select Committee, Q7357 (Lyttleton); Report p. 41. 1932/3 Royal Commission on Lotteries and Betting, report para. 204.

16 See Stevenson, British society 1914-45, p. 272.

171923 Select Committee, Q2377 (Hamilton).

18 For the extent of betting in Liverpool despite the economic difficulties of the period see Liverpool Council of Voluntary Aid, Report on betting in Liverpool (Liverpool: LCVA, 1926).

19 Mark Clapson, 'Playing the system: the world of organised street betting in Manchester, Salford and Bolton c.1880-1939', in Andrew Davies and Steven Fielding, Workers' worlds: cultures and communities in Manchester and Salford 18801939 (Manchester: Manchester University Press, 1992), p. 157.

20 See Chinn, Better betting, pp. 270-1.

211923 Select Committee, Q6206 (Gulland).

221923 Select Committee, Q4778 (Croll); QQ5039-41 (McLean).

23 1932/3 Royal Commission on Lotteries and Betting, report para. 131.

24 Chinn, Better betting, pp. 127-8

251923 Select Committee QQ4514-21 (Tyler).

26 More recent empirical research suggested that in the 1970s those who claimed to use skill, usually male, were far more likely to read both racing pages and the specialist racing press. See D. M. Downes, B. P. Davies, M. E. David and P. Stone, Gambling, work and leisure: a study across three areas (London: Routledge and Kegan Paul, 1976), p. 136.

27 Philip Corrigan and Paul Willis, 'Cultural forms and class mediations', Media, culture and society, 2:3 (1980), 306. 
28 See Downes et al., Gambling, work and leisure, p. 24.

29 Ross McKibbin, Classes and cultures: England 1918-1951 (Oxford: Oxford University Press, 1998), p. 375.

30 1932/3 Royal Commission, report para. 188.

31 Clapson, A bit of a flutter, p. 47; John K. Walton, Lancashire: A social history 1558-1939 (Manchester: Manchester University Press, 1987), p. 343; Chinn, Better betting, pp. 174-5.

32 Ross McKibbin, The ideologies of class (Oxford: Oxford University Press, 1990), p. 244.

33 Rowntree, Poverty and progress, p. 403.

34 1932-/ Royal Commission, report para. 216. Minutes of evidence, QQ5312-25 (Evans); QQ8826-8 (Denton).

351923 Select Committee, draft report para. 31.

36 The Pilgrim Trust, Men without work.

37 E. Wight Bakke, The unemployed man: a social study (London: Nisbet and Co., 1935), pp. 189-90, 199.

38 A point emphasised by Stephen Jones, Workers at play (London: Routledge, 1986), p. 92 .

391923 Select Committee, Q6759 (Green).

40 Liverpool Council of Voluntary Aid, Report on betting in Liverpool (Liverpool: LCVA, 1926).

41 See Seyla Benhabib, Situating the self: gender, community and post-modernism in contemporary ethics (London: Routledge, 1992), for a critique of such positions.

42 Alethea Melling, 'Wicked women from Wigan and other tales: licentious leisure and the social control of working-class women in Wigan and St Helens, 1914-1930', North-west labour history, 24 (1999/2000), 39.

43 Rowntree, Poverty and progress, p. 400.

441923 Select Committee, Q763ff.(Caldwell); Q4095 (Randall); Q5122-6 (Evans).

451923 Select Committee, Q5133 (Evans).

46 Chinn, Better betting, p. 170.

47 The Betting (Juvenile Messengers) (Scotland) Act, 1928.

481923 Select Committee, Q1369 (Bigham). Chinn, Better betting, p. 170 provides further examples.

49 Daily Telegraph, 6.2.1926.

50 1932-3 Royal Commission, minutes of evidence Q809.

511923 Select Committee, QQ8470, 8494-5 (Marshall).

52 Chinn, Better betting, p. 168.

531923 Select Committee, para. 35.

54 Rowntree, Poverty and progress, p. 402.

55 Chinn, Better betting, pp. xii, xiii. This continued the dominant picture of earlier anti-gambling writers. See M. J. Huggins, 'The first generation of street bookmakers in Victorian England: demonic fiends or decent fellers?', Northern history, 36: 1 (2000), 133. 
56 Chinn, Better betting, pp. 232-6 and passim.

57 Walter Haydn Davies, Blithe ones (Bridgend: Bridgend Printing, 1979), p. 97.

581923 Select Committee, report, p. xiii.

591923 Select Committee, Q1366 (Bigham); Q780 (Caldwell); Q9048 (Denton).

60 1932-3 Royal Commission, minutes of evidence Q736. See also Clapson, A bit of a flutter, pp. 58-9.

61 For example, The Times, 25.8.1937; ibid., 19.2.1938.

621923 Select Committee, draft report, p. xxxvi; 1932/3 Royal Commission, report para. 130.

631923 Select Committee, Q8298 (Yates).

64 Chinn, Better betting, pp. 187-8.

65 1932/3 Royal Commission, report para. 126.

661923 Select Committee, Q4798 (Croll).

67 Rev. Peter Green, Betting and gambling (London: Student Christian Movement, 1934), pp. 54-63.

68 Chinn, Better betting, p. 168. Some nineteenth-century bookmakers were involved in a hard-drinking, fighting, more criminal subculture. See Huggins, 'The first generation of street bookmakers', pp. 130-45.

691923 Select Committee, Q290 (Thompson).

70 Mass Observation, The pub and the people (London: Cresset, 1987), pp. 178, 187, 262-5.

71 Chinn, Better betting, p. 127.

72 1932-3 Royal Commission, Q8603 (Marshall).

731923 Select Committee, Q3056-7 (Grieve).

74 See The Times, 28.6.1933; ibid., 10.1.1934; Clapson, A bit of a flutter, pp. 125-6.

75 Northern Daily Mail, 16.7.1921.

76 North-Eastern Daily Gazette, 21.5.1920; Chinn, Better betting, p. 123.

771923 Select Committee, report p. xiii.

781929 Royal Commission on Police Powers and Procedure, report paras 196-9, 280.

79 Dixon, Prohibition to regulation, pp. 262-6.

801923 Select Committee, Q1641 (Bigham).

811923 Select Committee, Q851-5.

821923 Select Committee, Q9045 (Denton).

831923 Select Committee, Appendix of District Conference of Chief Constables, District No 1. See also Dixon, From prohibition to regulation, pp. 219-56.

84 1932/3 Royal Commission, report para. 133.

851932 Select Committee, Q8610 (Marshall).

86 See R. Munting, 'Social opposition to gambling in Britain', International journal of the history of sport, 10:3 (Dec. 1993), 306.

87 Rowntree, Poverty and progress, p. 401.

88 Phil Welsh, Stable rat: life in the racing stables (London: Eyre Methuen, 1979), p. 32 .

89 Dixon, From prohibition to regulation, p. 223. 
90 McKibbin, Classes and cultures, p. 371.

91 1932/3 Royal Commission, report paras 199-200.

92 1932/3 Royal Commission, para. 117.

93 Richard Kaye, The Ladbroke's story (London: Pelham Books, 1969), p. 66.

94 Cleveland Standard, 23.6.1934.

95 London Evening News, 21.5.1937. See also another cartoon: 'Usefulness of opinions of barbers', Daily Mirror, 26.5.1935.

961923 Select Committee, Q554.

97 Elizabeth Dawson, Mother made a book (London: Geoffrey Bles, 1962), pp. 21, 27, 35.

98 For example, Gregory Blaxland, Golden Miller (London: Constable, 1972), p. xi.

99 Noel Fairfax-Blakeborough (ed.), J. F.-B: the memoirs of Jack Fairfax-Blakeborough (London: J. A. Allen, 1978), p. 182.

100 Sporting Life, 19.5.1924.

101 Theodore Felstead, Racing romance (London: Werner Laurie, 1949), pp. 100-2.

102 John Hislop, Far from a gentleman (London: Michael Joseph, 1960), p. 177.

1031923 Select Committee, QQ7957-67 (Heathorn). W. Bebbington, Rogues go racing (London: Good and Betts, 1947), pp. 120-1 took the same view.

1041923 Select Committee, Q2244 (Hamilton).

1051923 Select Committee, report p. 41; Q749 (Caldwell); Q1368 (Bigham); QQ6781, 6782 (Green); Q4543 (Tyler); Q6856 (Green).

106 Turf Guardian Society, Directory of turf accountants and commission agents (London: TGS, 1921).

1071923 Select Committee, Appendix 3 and QQ745-9 (Caldwell); Q8277 (Randall); QQ4049, 8473, 8524 (Marshall). See The Times, 24.4.1923 for the anti-duty conference the Turf Guardian Society organised.

108 Quoted in The Times, 21.4.1923.

1091923 Select Committee, Q1257; Q4751-4 (Croll).

1101923 Select Committee, QQ4890, 4893, 4898, 4900 (McLean).

111 C. R. Acton, Silk and spur (London: Richards, 1935), p. 209. Norman Pegg, Focus on racing (London: Robert Hale, 1963), pp. 94-5.

112 Ruff's guide to the turf, 1933, p. viii.

1131923 Select Committee QQ3356-62 (Randall).

114 Sporting Chronicle, Flat racing up to date: yearly part 1938 (Manchester: Sporting Chronicle, 1938), frontspiece.

115 Sporting Life, 22.2.1924.

116 1932-3 Royal Commission, paras 120-1.

117 Sporting Chronicle, 27.3.1935.

1181923 Select Committee, QQ3665, 3758, 3804, 3911 (Crump). See also Munting, 'Social opposition to gambling', p. 306; and Kaye, The Ladbroke's story.

119 1932/3 Royal Commission, report para. 117.

120 Munting, History of gambling, p. 102.

121 Charles Sidney, The art of legging (London: Maxline International, 1976), pp. 74-5. 1923 Select Committee, Q8211 (Heathorn). 
122 Jack Fairfax-Blakeborough, The analysis of the turf(London: Philip Allan, 1927), p. 265.

123 Felstead, Racing romance, p. 127.

124 Chinn, Better betting, p. 193.

1251923 Select Committee, Q2851 (Hawkins).

126 See Clapson, A bit of a flutter, pp. 31, 122.

127 The Sporting Chronicle began analysing the effects of such systems, and the relative success of different sporting tipsters, in the 1920s.

128 See Clapson, A bit of a flutter, p. 62.

129 See Barbara O'Connor and Elisabeth Klaus, 'Pleasure and meaningful discourse: an overview of research issues', International journal of cultural studies, 3:3 (2000), 369-87.

130 Liverpool Echo, 20.3.1930.

1311923 Select Committee, report p. 42.

132 Duggan was regularly prosecuted in Britain. See The Times, 29.6.1923 and 14.6.1924 for examples. He maintained a London office, e.g. Sporting Life 28.5.1924. For the Monte Carlo sweep see the Sportsman, 29.3.1924.

133 Liverpool Post, 27.3.1925.

134 Sidney Galtrey, Memoirs of a racing journalist (London: Hutchinson, 1934), pp. 263-6.

135 Daily Mirror, 25.5.1925.

136 See The Times, 21-23.6.1923.

137 The Times, 30.5.1933.

138 A. Edward Newton, Derby day and other adventures (Boston: Little, Brown and Co., 1934), p. 9.

139 The Times, 7.2.1933.

140 The Times, 7.2.1933.

141 The Times, 29.1.1920; ibid., 16.2.1920.

142 The following section draws heavily on Clapson, A bit of a flutter, pp. 190-3.

143 C. L'Estrange Ewen, Lotteries and sweepstakes (London: Heath Cranton, 1932), p. 350.

144 In 1933, for example, of those who drew Derby horses for the $£ 30,000$ prizes, only one came from Ireland, one from Switzerland and three from North America; and fourteen were British.

145 The Times, 1.6.1933.

146 Daily Express, 11.11.1930.

147 The Times, 22.6.1933; ibid., 24.6.1933.

148 'Britain's betting industry - II', Economist, 7.3.1936, p. 517; Chinn, Better betting, p. 228. 